\title{
PRIVATE ACTIONS AND THE PROXY RULES: THE BASIS AND THE BREADTH OF THE FEDERAL REMEDY
}

The extent of the federal remedy available to a person injured by a violation of the proxy rules issued under section 14(a) of the Securities Exchange Act of $1934^{1}$ is now before the United States Supreme Court in J. I. Case Co. $v$. Borak. ${ }^{2}$ The second count of plaintiff's third amended complaint alleged a violation of sections $10(\mathrm{~b})$ and $14(\mathrm{a})^{3}$ of the 1934 act. ${ }^{4}$ The plaintiff claimed that the material soliciting proxies for a shareholder election to approve a merger with American Tractor Company was false and misleading in failing to reveal the benefits to accrue to Case directors from the merger. Borak sought a declaration that the proxy solicitation material was false and misleading, that the proxies solicited thereby were illegal and void and that the merger and all agreements entered into pursuant to it were void. He also asked damages for the injuries sustained by himself and other shareholders similarly situated from the alleged violation of the act. 5

The defendant moved that Borak be ordered to provide security for expenses required in derivative actions under Wisconsin law. ${ }^{6}$ Ruling on the motion, the district court held that count two stated no cause of action under section $10(\mathrm{~b})$ of the 1934 act, and that under Dann v. Studebaker-Packard Corp. ${ }^{7}$ the only relief the court had federal

148 Stat. 881, 895 (1934), 15 U.S.C. $\$ \$ 78,78 \mathrm{n}(1958)$.

2 Borak v. J. I. Case Co., 317 F.2d 838 (7th Cir.), cert. granted, 375 U.S. 901 (1963).

348 Stat. 891, 895 (1934), 15 U.S.C. $\$ \S 78 j(b), 78 n(a)(1958)$.

4 Count one was a diversity claim based on Wisconsin law alleging self dealing by directors and violation of their fiduciary duties to shareholders. The plaintiff sought a judgment ordering the issuance of Case stock to him and the class he represented in accordance with their pre-emptive rights or, in the alternative, damages or other relief. The court of appeals held that the district court judge had been correct in his conclusion that the facts alleged in count one were basically consistent with the statement of a derivative cause of action under Wisconsin law, but also held that the allegations would support a cause of action under state law for the redress of rights individual to shareholders. The court concluded, therefore, that since a cause of action on behalf of stockholders individually was alleged, the district court erred in holding the provisions of the Wisconsin security for expenses statute applicable. 317 F.2d 838, 842-45 (7th Cir. 1963).

5 The court's jurisdiction was invoked on grounds of diversity; section 27 of the Exchange Act, 48 Stat. 902-03 (1934), as amended, 15 U.S.C. \& 78aa (1958); and sections 1331 and 1337 of the Judicial Code, 28 U.S.C. \$\$ 1331, 1337 (1958). The court of appeals dismissed the diversity allegations of count 2 as surplusage, 3I7 F.2d at 847 n.10.

6 Wis. Stat. Ann. 180.405(4) (1957).

7288 F.2d 201 (6th Cir. 1961). 
question jurisdiction to grant for section 14(a) violations was a declaratory judgment as to the validity; of the proxies. The district court ruled that any further relief requested could only be granted under the court's diversity jurisdiction and was subject to the state security for expenses statute. Plaintiff having refused to post security, the count was dismissed except for those portions which constituted a claim for a declaration of proxy invalidity.

On appeal the Seventh Circuit held that federal question jurisdiction empowered the district court "to award damages or such other retrospective relief . . . as the merits of the controversy may require" 8 for violations of the proxy rules. The Seventh Circuit held that since the remedies requested could be granted under the federal statute the plaintiff was not required to post security for expenses as required by state law. ${ }^{9}$

The Seventh Circuit's holding in Borak conflicts with the Sixth Circuit's holding in Dann v. Studebaker-Packard Corp. ${ }^{10}$ Dann was a nondiversity action in which the shareholder plaintiffs alleged violation of the proxy rules and asked that the proxies given in response to the offending solicitation be declared void and that the court recount the shareholders' vote approving a disposition of assets to the Curtiss-Wright Corporation. If the vote of approval, discounting the invalid proxies, was not by the requisite two-thirds majority of the outstanding stock the court was asked to return Studebaker-Packard to the economic position which it had before the disposition of assets was consummated. The district court granted a motion to dismiss. On appeal, the Sixth Circuit held, first, that section 14(a) gave the plaintiffs a right of action, but only for declaratory relief, and that the plaintiffs had standing to bring the action though they had not themselves given proxies in response to the offending solicitation.11 Turning to the nature of the right created by the proxy section, the court found it to be the "right to the free exercise of the corporate franchise," a right "which can only be enjoyed and exercised by the individual shareholder and, therefore, is personal and primary to him." 12 As to the remedy, the court observed:

8317 F.2d at 849 .

9 Ibid. Accord, McClure v. Borne Chem. Co., 292 F.2d 824 (3d Cir.), cert. denied, 368 U.S. 939 (1961); Fielding v. Allen, 181 F.2d 163 (2d Cir.), cert. denied sub nom. Ogden Corp. v. Fielding, 340 U.S. 817 (1950); Breswick \& Co. v. Briggs, 136 F. Supp. 301 (S.D.N.Y. 1955), cert. denied, 351 U.S. 967 (1956).

10288 F.2d 201 (6th Gir, 1961).

11 Id. at 209, 210.

12 Id. at 210-11. The Dann court emphasized the personal, as opposed to the derivative right of a shareholder to institute the action and thereby distinguished Howard v. Furst, 238 F.2d 790 (2d Cir. 1956), affirming 140 F. Supp. 507 (S.D.N.Y. 1956), cert. denied, 353 U.S. 937 (1957). In that case the district court dismissed a suit, denominated derivative by the plaintiff-shareholders, to rescind a sale of assets based 
[T] he legislative history ... shows that the personal right sought to be protected thereby is the right to full and fair disclosure, which best could be insured through the utilization of prospective, rather than retrospective, sanctions. Obviously the most effective sanction would be one which tends to prevent, rather than to remedy, the injection of misleading statements into a proxy fight. ${ }^{13}$

Though prospective sanctions are the most desirable form of relief, it need not follow that other remedies are precluded when the "prospective" sanction fails. Otherwise a violator need only be clever enough to keep his proxy violation from the SEG and the public until the election is

on proxy rule violations by directors. The court dismissed for lack of subject matter jurisdiction on the ground that $\S 14$ (a) created no substantive right of the corporation, and, therefore, the plaintiff could not maintain the action derivatively in the right of the corporation. The plaintiff's motion to amend to allege an individual claim for relief was denied by the district court on the ground that rescission could not be granted, on reasoning similar to that used by the court in Dann. On appeal, the Second Circuit affirmed the earlier dismissal of the claim for derivative relief, but explicitly left undecided the propriety of claiming the same relief individually. 238 F.2d at 793.

It is submitted that the characterization of the action under state law as individual or derivative is not a proper basis on which to condition relief. The purpose of $\S 14(a)$ is to protect shareholders, and artificial notions of "directness of the injury" should not be conclusive. On occasion courts have refused to be bound by the categorization of the injury as direct or indirect in determining whether relief should run to the corporation or to the shareholders. See, e.g., Perlman v. Feldman, 219 F.2d 173 (2d Cir.), cert. denied, 349 U.S. 952 (1955), where the court granted individual recovery to certain shareholders in a derivative suit to avoid giving a windfall to the controlling group of shareholders. Professor Loss has intimated that Howard v. Furst, supra, is a pleading case, and that if the plaintiffs claimed individual relief, whatever the characterization under state law, that might suffice. 2 Loss, Securities REGULATION 952 (1961). If that is the impact of Howard $v$. Furst, such an approach is unduly formalistic.

Nor is the characterization as derivative or individual made crucial because of state security for expense statutes, for "derivative" actions arising under federal law are not subject to such statutes. McClure v. Borne Chem. Co., 292 F.2d 824 (3d Cir.), cert. denied, 368 U.S. 939 (1961); Fielding v. Allen, 181 F.2d 163 (2d Cir.), cert. denied sub nom. Ogden Corp. v. Fielding, 340 U.S. 817 (1950); Breswick \& Co. v. Briggs 136 F. Supp. 301 (S.D.N.Y. 1955), cert. denied, 351 U.S. 967 (1956).

The characterization may be relevant in determining whether procedural requirements are applicable. For example FED. R. Crv. P. 23(b) requires a demand on directors in secondary, i.e., derivative, shareholder suits. 3 MOORE, Federal Practice đI 23.16[1] (2d ed. 1948). In federal question cases, doubtless federal common-law characterization of whether the suit is derivative is applicable to determine whether rule 23(b) applies.

The difficulty in characterizing a private action under section 14(a) arises from the fact that it has attributes of both a derivative and an individual action. If the test of what is derivative is whose rights are being protected, private actions for proxy violations are not derivative. But if the test is who has been directly damaged, these actions can often be characterized as derivative since the damage usually alleged-as in Borak-is to the corporation, and the primary recovery, in the event of rescission of a merger, is to the corporation.

13288 F.2d at 211. 
won. ${ }^{14}$ But in considering whether "retrospective"15 relief should be made available, the court noted that "unless we are to abandon altogether any concept of a dichotomy of federal and state jurisdiction in this area, it is clear that a line must be drawn somewhere to mark the limits of federal jurisdiction."16 The court decided that:

14 Reasons other than undisclosed fraud or misrepresentation may necessitate relief after the meeting if enforcement of the act is to be effective. Even where there was no suggestion of laches, meetings have been held before action could be taken causing the courts to dismiss, on the grounds that the question of injunctive relief had become moot. See, e.g., SEC v. Topping, 85 F. Supp. 63 (S.D.N.Y. 1949); Doyle v. Milton, 73 F. Supp. 281 (S.D.N.Y. 1947). Though criminal penalties are provided by the act, prosecutions for proxy violations have been virtually non-existent. See, however, United States v. Guterma, 189 F. Supp. 265 (S.D.N.Y. 1960); United States v. Pope, 189 F. Supp. 12 (S.D.N.Y. 1960). Moreover, criminal penalties do not compensate for the damage individual investors have suffered or retrieve the corporation from the adverse interests which may have won through proxy violations. Recognizing this, certain courts have spoken of their right to give equitable relief under $\$ 14(a)$. Speaking of such relief in an early leading case, the Third Circuit said: "We entertain no doubt that the court below possesses the authority to make any order necessary to enforce liabilities or duties created by the Act or rules promulgated pursuant thereto." SEC v. Transamerica Corp., 163 F.2d 511, 518 (3d Cir. 1947), cert. denied, 332 U.S. 847 (1948). And the southern district court of New York said: "II]f after a full hearing the court determines that proxies were unlawfully obtained and utilized, the election may be set aside and a resolicitation of proxies with full disclosure and a new election thereon may be had." Mack v. Mishkin, 172 F. Supp. 885,889 (S.D.N.Y. 1959). Borak, however, is the first case actually to provide for such relief.

15 The terms "prospective relief" and "retrospective relief" used in Dann and Borak are unfortunate since the temptation is presented to rely on them as the distinction between the type of relief each court thought it could grant. The Dann court appears to use "prospective relief" to mean sanctions applied before the injection of misleading proxy statements into circulation. See 288 F.2d at 211. Borak refers to damages and other "retrospective relief" without clarifying the latter term. In distinction to Dann's conception of prospective relief, Borak's retrospective relief should mean any relief after the injection of the proxy statements into circulation. Other possibilities are that "retrospective relief" means any relief granted after the meeting for which proxies were solicited is held, or after a corporate' act is consummated. In the Dann sense, "retrospective relief" has long been available to the SEC and to private parties. Courts have voided proxy contracts, postponed meetings and have given other similar relief. And the Dann court itself allowed retrospective relief in the sense of relief given after the meeting in allowing proxies to be declared void. For purposes of analysis it is better to discard the terms since they do not delineate the difference between the Dann and Borak courts, nor are they defined with precision-or even defined at all-in Dann and Borak. For purposes of description, in this comment the following terminology is adopted. "Prospective" relief means relief available before the solicitation material is circulated. "Preventive" relief means relief available before the votes are counted at an election of directors, or before a corporate act is consummated. And "retrospective" relief means relief available after the act is consummated. The distinction between preventive and retrospective is considered here to be the consummation of the act voted at the meeting rather than the meeting itself because after the meeting the directors may still abandon the project, see note 60 infra, and an injunction would serve as an appropriate remedy to prevent consummation. After consummation, the undoing of the act is a task of a different order.

16288 F.2d at 213. 
[F]ederal jurisdiction must end with the holding of a contested proxy election, .... the right created by Section 14(a) of the Exchange Act is only broad enough to permit consideration of the validity of the proxies solicited in violation thereof, but it is not broad enough to permit the federal courts to determine the consequent effects of the validity or invalidity of said proxies. This latter determination raises issues which concern matters of local law alone. In our opinion, this is the cleanest joint at which to amputate the long arm of federal law in this area. ${ }^{17}$

In so deciding, the Sixth Circuit did not concentrate on the scope of the federal right involved. It granted as much when it said:

[I] $f$ we should decide to limit federal judicial power, as a jurisdictional matter, purely to a determination of the validity of allegedly improperly solicited proxies, and to leave to the state courts their separate and exclusive jurisdiction to consider the consequent effects of such a determination ... we would be eating away at the vital principle that for every federal right, there should be a complete federal remedy. ${ }^{18}$

Thus the court suggested that complete vindication of the federal right would require a broader remedy, but because of federal-state comity considerations it continued:

[S]hould we hold that the federal courts have jurisdiction, quite apart from diversity of citizenship, to determine matters of state law which are wholly independent of the federal issues before the court, we would erode even further the equally vital principle of separate sovereignties which underlies the Constitutional and statutory definitions of "the judicial power of the United States." Furthermore, in these days of already overburdened federal trial dockets, it might well be a disservice to the federal judiciary to extend its domain into an area so predominantly governed by state and local law. This, we are unwilling to do. ${ }^{19}$

In deciding the Borak case, the Supreme Court will be ruling on a motion to post security for expenses. But in order to decide whether it is necessary for the plaintiff to comply with the Wisconsin security for expenses statute, it must first decide the nature of the federal right under section 14(a). The conflict between Dann and Borak thus turns on how an action under section 14(a) asking for rescission of a sale of assets or merger is characterized. Is it an action, controlled by state law, based on the theory that the corporate act was ultra vires because the share-

17 Id. at 214.

18 Ibid.

19 Ibid. 
holder vote was void? Or is it principally a federal action seeking to further the federal disclosure policies of section 14(a) for which state law is relevant only to determine the appropriate remedy?

Dann adopts the first characterization, holding that the only federal question presented is the validity of the proxies. Consequently, any determination by a federal court of the possible effect of the proxy invalidity on subsequent corporate action is a question which the court has power to decide only under its diversity jurisdiction. Cohen v. Beneficial Industrial Loan Corp. ${ }^{20}$ requires compliance with the state security for expense statute. On the other hand, if the damage and rescission remedies are in vindication of a federal right to full disclosure, the court's jurisdiction is based entirely upon a federal question. It is then unnecessary to comply with the state security for expense statute ${ }^{21}$ because such a requirement would impede vindication of the federal policy.

\section{The Statute}

The conflict between Dann and Borak can only be resolved by a careful examination of the statute and the reasoning by which the courts have recognized private rights of action under it. The congressional debates and reports indicate that the act was intended to "reach the causes of unfair, unwise, and destructive speculation ... to regulate the stock exchanges and the relationship of the investing public to the corporations which invite public investment by listing on such exchanges." 22 The desire of Congress was to bring "safety to the general public in the field of investment and finance" 23 by policing the exchanges, by prohibiting certain practices and by requiring full disclosure which was to throw "the white light of publicity" upon the actions and interests of the men controlling the exchanges, the corporations and securities transactions. ${ }^{24}$

Section 14(a) provides:

It shall be unlawful for any person, by the use of the mails or any means or instrumentality of interstate commerce or of any facility of any national securities exchange or otherwise to solicit or to permit the use of his name to solicit any proxy or consent or authorization in respect of any security (other than an exempted security) registered on any national securities exchange in contravention of such rules and regulations as the Commis-

20337 U.S. 541 (1949).

21 See cases collected at note 9 supra.

22 H.R. REP. No. 1383, 73d Cong., 2d Sess. (1934).

2378 Cong. REc. 2270 (1934) (remarks of Sen. Fletcher, principal Senate sponsor of the bill).

2478 Cong. Rec. 7925 (1934). 
sion may prescribe as necessary or appropriate in the public interest or for the protection of investors. ${ }^{25}$

By its rules and regulations the SEC was to require full disclosure of matters affecting corporate elections by proxy. Publicity, it was thought, would be sufficient to prevent abuses. ${ }^{26}$ The then recently decided American Tobacco Company cases ${ }^{27}$ involving large salaries and bonuses voted officers were mentioned in the House of Representatives as specific examples of the kind of proxy abuse to be prevented by disclosure. ${ }^{28}$

The SEG rules require proxy solicitation material to contain certain specified information and to be filed with the Commission ten days before the mailing to shareholders. ${ }^{29}$ The SEC has, on its own, no statutory power to compel the correction or prevent the use of material violating the proxy rules. Persuasion and other informal methods have been developed to secure compliance. ${ }^{30}$ If these fail, the SEG has power under section $21(e)^{31}$ to bring an action in a United States district court to enjoin "acts or practices" which violate the act. The same section authorizes the Commission to transmit to the Attorney General evidence of these "acts or practices," so that the Attorney General may, in his discretion, institute criminal proceedings under the criminal penalty provided in section $32^{32}$ for willful violations of the act.

An extraordinary feature of the 1934 act is the grant, in section $27,{ }^{33}$ of exclusive jurisdiction to the federal courts. Sound considerations of uniformity of administration, of sympathy with the purposes of the statute and of greater technical proficiency to hear cases arising under the act could have been reasons for exclusivity. The provision and its implica-

2548 Stat. 895 (1934), 15 U.S.C. $\$ 78 n$ (a) (1958).

26 Sen. Fletcher, chairman of the Committee on Banking and Currency and, with Rep. Rayburn, a co-sponsor of the bill, said of the proxy section: "The great evil involved in the abuse of proxies is dealt with by the bill. Men with small, and sometimes no, financial interest will be unable under this bill to solicit proxies without disclosing their real interest and all their side agreements and special privileges and special relationships, of which the stockholders of the companies should be fully informed. ... [P]rovisions of the bill ... strike the first blow at a system that has given a small and willful group of men control over the property and savings of the great mass of investors." 78 Conc. REc. 2271 (1934).

27 Rogers v. Hill, 289 U.S. 582 (1933); Rogers v. Guaranty Trust Co., 288 U.S. 123 (1933).

28 See 78 Cong. Rec. 7923 (1934).

20 See 17 C.F.R. § 240.14a(1)-(11) (1949).

30 Armstrong, The Role of the Securities Exchange Commission in Proxy Contests of Listed Companies, II Bus. LAw. 110 (Nov. 1955); Orrick, The Revised Proxy Rules of the Securities and Exchange Commission, 11 Bus. LAw 32 (April 1956).

3148 Stat. 899 (1934), as amended, 15 U.S.G. $\$ 78 \mathrm{u}(\mathrm{e})$ (1958).

3248 Stat. 904 (1934), as amended, 15 U.S.C. $\$ 78$ ff (1958).

3348 Stat. 902 (1934), as amended, 15 U.S.C. $\$ 78$ aa (1958). 
tions do not appear to have been carefully considered in Congress, however. ${ }^{34}$ Because of section 27 state courts have held that they are precluded from hearing actions based on the 1934 act.35 As a result, a plaintiff seeking rescission or damages under the Dann rule would be forced to bring his case in two different courts. The state courts would be foreclosed by section 27 from determining the validity of the proxies. And the federal courts would be foreclosed from affording meaningful relief under Dann. Although these difficulties are not controlling, they should be kept in mind in any consideration of the merits of the Dann court's reasoning.

Two sections are of particular importance for private actions under the act. Section $28^{36}$ provides that no person "permitted to maintain a suit for damages under the provisions of this chapter shall recover ... a total amount in excess of his actual damages. ..." Section $29^{37}$ provides that any contract made in violation of the provisions of the act shall be void as to the rights of violators and those acquiring rights under the contract with knowledge of the violation.

If these were the only provisions in the act dealing with private actions a persuasive argument could be made that sections 28 and 29 create sweeping civil remedies under all the substantive sections of the act. Complexity arises from the fact that three substantive sections of the act, sections $9(\mathrm{e}), 16(\mathrm{~b})$ and $18,^{38}$ explicitly provide for individual suits. This feature has led to considerable controversy over whether Congress intended to allow private civil actions for violations of other sections of the act, particularly sections 10 and 14 .

The argument of expressio unius exclusio alterius based on the three sections with specific liability provisions has been generally rejected. Professor Loss argues against it. ${ }^{39}$ The Second Circuit has pointed out

34 The only evidence of consideration of the exclusivity provision is a statement of Rep. Rayburn, the principal House sponsor, during debate on amendments in the House. He moved to amend by inserting the word "exclusive," saying: "I have only this to say-that we thought the bill as drawn meant exclusive, but in order that it may be entirely clear we offer this amendment." 78 CoNG. REc. 8099 (1934).

35 American Hardware Corp. v. Savage Arms Corp., 136 A.2d 690 (Del. 1957); Standard Power \& Light Corp. v. Investment Associates, Inc., 29 Del. Ch. 593, 51 A.2d 572 (Sup. Ct. 1947); Eliasberg v. Standard Oil Co., 23 N.J. Super. 431, 92 A.2d 862 (Ch. 1952); Malkan v. General Transistor Corp., 27 Misc. 2d 677, 207 N.Y.S.2d 345 (Sup. Ct. 1960). See generally 2 Loss, op. cit. supra note 12, at 977-1001.

3648 Stat. 903 (1934), 15 U.S.C. $\$ 78 b b$ (1958).

3748 Stat. 903 (1934), as amended, 15 U.S.C. $\$ 78 \mathrm{cc}(1958)$.

3848 Stat. 889 (1934), 15 U.S.C. \& 78i(e) (1958); 48 Stat. 896 (1934), 15 U.S.C. \& 78p(b) (1958); 48 Stat. 897 , as amended, 15 U.S.C. $\$ 78 \mathrm{r}$ (a) (1958).

392 Loss, op. cit. supra note 12, at 937-46; cf. SEC v. C. M. Joiner Leasing Corp., 320 U.S. 344, 350-51 (1943); Dann v. Studebaker-Packard Corp., 288 F.2d 201, 208-10 (6th Cir. 1961); Note, 62 Colum. L. REv. 375 (1962). 
that the three sections deal with special matters, providing more liberal remedies than would be available under the common-law doctrine of implied civil remedies and establishing special statutes of limitation, and therefore do not foreclose implied civil remedies under the other sections. ${ }^{40}$ It has also been argued that the amendment to section $29(\mathrm{~b})$ providing a specific statute of limitation for actions under section 15 , which does not explicitly mention private remedies, shows that Congress assumed that private actions were available under all the sections of the act. ${ }^{41}$

\section{Private Actions}

Although the Supreme Court has never ruled on the matter, the lower federal courts have been virtually unanimous in allowing private actions for violations of sections $10(\mathrm{~b})^{42}$ and $14(\mathrm{a}) .^{43}$ At this late date in the development of the judicial interpretation of the 1934 act, the existence of private rights of action under the two sections seems incontrovertibly established. The important question now is not does such a right exist, but what is its scope? Under section 14(a) this is a difficult question because there are three different lines of reasoning which result in the recognition of private remedies for violations of the section. These are: (1) an implied civil remedy based on the criminal provisions, (2) an action for preventive relief based on the theory that the private plaintiff is acting to aid the SEC in enforcement of the act, and (3) an action for rescission based on the provision in section 29 voiding contracts made in violation of the act.

Some cases recognizing private actions rely on the tort doctrine that violation of a statute or regulation prohibiting certain conduct gives rise to a civil action on the part of those within the class intended to be

40 Baird v. Franklin, 141 F.2d 238, 244-45 (2d Cir. 1944), cert. denied, 323 U.S. 737 (1944).

41 Note, 77 HaRv. L. REv. 285, 290 \& n.36 (1963).

42 See, e.g., McClure v. Borne Chem. Co., 292 F.2d 824 (3d Cir.), cert. denied, 368 U.S. 939 (1961); Ellis v. Carter, 291 F.2d 270 (9th Cir. 1961); Matheson v. Armbrust, 284 F.2d 670 (9th Cir. 1960); Fischman v. Raytheon Mfg. Co., 188 F.2d 783 (2d Cir. 1951); Pettit v. American Stock Exch., CGH FED. SEc. L. REP. I 91208 (S.D.N.Y. March 7, 1963); Greenwich Savings Bank v. Shields, 131 F. Supp. 368 (S.D.N.Y. 1955); Northern Trust Co. v. Essaness Theatres Corp., 103 F. Supp. 954 (N.D. Ill. 1952); Kardon v. National Gypsum Co., 73 F. Supp. 798 (E.D. Pa. 1947).

43 Brown v. Bullock, 194 F. Supp. 207 (S.D.N.Y.), aff'd, 294 F.2d 415 (2d Cir. 1961); Central Foundry Co. v. Gondelman, 166 F. Supp. 429 (S.D.N.Y. 1958); Rosen v. Allegheny Corp., 133 F. Supp. 858 (S.D.N.Y. 1955); Textron v. American Woolen Co., 122 F. Supp. 305 (D. Mass. 1954); Horwitz v. Balaban, 112 F. Supp. 99 (S.D.N.Y. 1949). Contra, Howard v. Furst, 140 F. Supp. 507 (S.D.N.Y.), aff'd, 238 F.2d 790 (2d Cir. 1956), cert. denied, 353 U.S. 937 (1957). 
protected who are injured by the violation.44 The Dann court rejected arguments against a private right of action under section 14(a) "in the light of the long established general rule that a breach of a statutory duty normally gives rise to a right of action on behalf of the injured persons for whose benefit the statute was enacted." 45 In reference to an alleged section 14(a) proxy violation in Brown $v$. Bullock the court said that "since the Act and the regulations thereunder make the use of false proxy statements 'unlawful,' the persons for whose protection the Act was designed are entitled to relief from the alleged wrongdoers." 46 This tort theory, however, normally only supports an action for money damages or, in the proper case, an injunction against continuing violations. ${ }^{47}$ And even if equity might afford the plaintiff an additional remedy on the theory that there is no adequate remedy at law, that relief could only run against the violators who have committed the tort-not against the corporation. The Dann court was extending the doctrine in applying it to an action for a declaration of proxy invalidity. Where a private plaintiff can show that he has been injured by the defendant's violation of the proxy rules, the implied civil remedy theory would allow him to recover damages. For this reason, the damage claim in Borak stands on a substantially different footing than the request for a declaration of the invalidity of the proxies and the merger.

A private action may also be allowed on the theory that permitting such actions will supplement the enforcement efforts of the SEC. This theory is implicit in the argument favoring a private action on the ground that an individual claiming a violation on the part of an adversary in a proxy contest who could not convince the SEC to bring an action would have no redress if the private action were disallowed. ${ }^{48}$ The reasoning of the Southern District of New York in Mack v. Mishkin ${ }^{49}$ also seems to rely on this theory. Refusing to grant a preliminary injunction to enjoin the use of proxies, the district judge argued that since Professor Loss says that the SEC can, in appropriate circumstances, bring an action to set aside corporate action, so, too, could the private plaintiff if the

44 In regard to the doctrine of implied civil actions generally, see Nixon v. Herndon, 273 U.S. 536 (1927); RESTATEMENT, TORTS \$ 386 (1934); 2 Loss, op. cit. supra note 12, at 931-46; Note, Implying Civil Remedies From Federal Regulatory Statutes, 77 HARv. L. Rev. 285 (1963); Note, 48 Colum. L. Rev. 456 (1948); Comment, 14 U. Chr. L. Rev. 471 (1947).

45288 F.2d at 208-09.

46194 F. Supp. 207, 231 (S.D.N.Y. 1961).

47 See, e.g., cases cited or discussed in 2 Loss, op. cit. supra note 12, at 932-46. See also Note, 48 Colum. L. REv. 456 (1948).

48 See Phillips v. United Corp., 5 S.E.C. JUd. Dec. 445 (S.D.N.Y. 1947); 2 Loss, op. cit. supra note 12 , at $945-46$.

49172 F. Supp. 885 (S.D.N.Y. 1959). 
facts should later prove to justify it. "I . . . see no reason why a private party cannot seek and obtain the same relief." 50

If recognition of a private action under section 14(a) rests on a conception of the private party helping the SEC to enforce the act, then the remedies afforded the private party should be the same as those available to the SEC. At the behest of the SEC, the courts have enjoined the solicitation of proxies, ${ }^{51}$ postponed or adjourned shareholder meetings, enjoined the voting of proxies ${ }^{52}$ and declared proxies void or invalid.53 But in all of these cases the shareholder votes had not yet been counted when the court acted. Professor Loss points out that the language of section 14(a) only proscribes solicitation. He argues:

If a court can enjoin the use of the proxies, can it take the next step and enjoin the consummation of the action purportedly approved by use of the proxies-or the step after that and set aside the action after it has been consummated? These differences are differences only of degree. The Rubicon was crossed when the courts began to enjoin the use of the proxies notwithstanding the literal limitation of their statutory injunctive power to restraining further illegal solicitations. ${ }^{54}$

It is submitted that setting aside a consummated action is so great a difference "of degree" from enjoining actions as to constitute a difference in kind. But if the SEC does have the power to set aside the action after it has been consummated, it could be argued that a private party does also. However, Professor Loss' argument looks only to section 14(a). Section 21(e), the section which authorizes the SEC to bring an enforcement action, provides:

Whenever it shall appear to the Commission that any person is engaged or about to engage in any acts or practices which constitute or will constitute a violation of the provisions of this chapter, or of any rule or regulation thereunder, it may in its discretion bring an action in the proper district court of the United States ... to enjoin such acts or practices, and upon a proper showing a permanent or temporary injunction or restraining order shall be granted . . . .5

50 Id. at 889.

51 SEC v. May, 229 F.2d ${ }^{\circ} 123$ (2d Cir. 1956); SEC v. Transamerica Corp., 163 F.2d 511 (3d Cir. 1947), cert. denied, 332 U.S. 847 (1948); SEC v. O'Hara Reelection (or Proxy) Committee, 28 F. Supp. 523 (D. Mass. 1939).

52 SEC v. May, supra note 51; SEC v. Transamerica Corp., supra note 51.

53 SEC v. May, supra note 5I; SEC v. Transamerica Corp., supra note 5I; SEC v. Okin, 58 F. Supp. 20 (S.D.N.Y. 1944); SEC v. O'Hara Reelection (or Proxy) Comm., 28 F. Supp. 523 (D. Mass. 1939).

542 Loss, op. cit. supra note 12 , at 960.

5548 Stat. 899 (1934), as amended, 15 U.S.C. $\$ 78 u(e)(1958)$. 
It is an extension of section 14(a) to hold that voting a proxy solicited in contravention of the rules is a violation of the section. Nevertheless in that case the "act or practices" being enjoined are the acts of violators -those who solicited the proxies. To go further and enjoin a corporate act which was approved at a shareholder's meeting would be to enjoin the acts of a non-violator-the corporation. To give the SEC standing to bring an action to enjoin corporate acts after the vote has been taken would require not only an extension of section 14(a), but an extension of section $2 \mathrm{l}(\mathrm{e})$. When the voting of proxies solicited in violation of the rules is enjoined, the violators are deprived of the fruits of their violation. But section $14(\mathrm{a})$ is not designed to regulate corporate acts, and a corporation which acts pursuant to a shareholder's mandate-even if that mandate was obtained in violation of section 14(a)-is not violating the act. But if the SEC does not itself have standing to bring an action to set aside a corporate act, then it is difficult to argue that a private plaintiff should be given the right to bring such an action on the theory that it supplements the enforcement efforts of the SEC.

A third theory in support of a private action is based on section $29(\mathrm{~b})$ of the 1934 act. Section 29 (b) provides:

Every contract made in violation of any provision of this chapter or of any rule or regulation thereunder, and every contract ... the performance of which involves the violation of, or the continuance of any relationship or practice in violation of, any provision of this chapter or rule or regulation thereunder, shall be void (1) as regards the rights of any person who, in violation of any such provision, rule, or regulation, shall have made or engaged in the performance of any such contract, and (2) as regards the rights of any person who, not being a party to such contract, shall have acquired any right thereunder with actual knowledge of the facts by reason of which the making or performance of such contract was in violation of any such provision, rule, or regulation . ...56

Section 29 (b) has explicitly been held to apply to section 10 of the act, ${ }^{57}$ and as a matter of statutory interpretation, there is no reason why it should not apply to section 14 as well. At one extreme, it could be argued that the contract for the sale of corporate assets or the merger may itself

5648 Stat. 903 , as amended, 15 U.S.C. $\S 78 \mathrm{cc}$ (b) (1958).

57 Errion v. Connell, 236 F.2d 447 (9th Cir. 1956); Kardon v. National Gypsum Co., 69 F. Supp. 512 (E.D. Pa. 1946); cf. Matheson v. Armbrust, 284 F.2d 670 (9th Cir. 1960); Greenwich Savings Bank v. Shields \& Co., 131 F. Supp. 368 (S.D.N.Y. 1955); Geismar v. Bond \& Goodwin, 40 F. Supp. 876 (S.D.N.Y. 1941). See also Royal Air Properties, Inc. v. Smith, 312 F.2d 210 (9th Cir. 1962). But see Goldenburg v. Bache \& Co., 270 F.2d 675 (5th Cir. 1959); Warshow v. Hentz \& Co,, 199 F. Supp. 581 (S.D.N.Y. 1961) (action barred by the statute of limitations of section $29(\mathrm{~b}))$. 
be voided by applying section $29(\mathrm{~b})$ if there has been a proxy violation in soliciting votes approving the action. Such a far reaching remedy based directly on section 29(b) was rejected by the Second Circuit in affirming dismissal of a claim seeking to void a contract for sale of corporate assets because of proxies falsely solicited. Though the court split on all the other counts, all three members agreed:

[section $29(\mathrm{~b})]$. . . relates solely to a contract made in violation of "any provision" of the Act or of "any rule or regulation thereunder." Here the contract [for sale of assets] itself was not thus violative .... So that, even if the allegations stated a violation of the Rule, the dismissal [by the district court] was correct. ${ }^{58}$

A better interpretation is that the contract to which section 29(b) refers is the proxy contract. 59 The parties to the proxy contract are the shareholder and the person authorized to vote the proxy. The difficult problem of interpretation in the context of section 14(a), then, is the phrase "shall have acquired any right thereunder." Does this include those who have acquired rights, or at least inchoate rights, ${ }^{60}$ from a corporate election? Clearly the individual authorized to exercise the proxy contract has rights under it. If he has engaged in the violation or knows of it, his rights are void under section 29(b). But what, for instance, of a director who has been elected to office partly on the basis of illegally solicited proxies? Does he have rights under the proxy contract? Conceptually, he does not. Up until the time the proxy was voted he had no rights because the proxy was revocable at will. And after the election, his rights come not from the proxy, but from his election. Such a limited interpretation of "rights," however, would lead to clearly undesirable results. For if only the person who is authorized to cast the proxy has rights under the proxy contract (other than the shareholder) and he is a violator or has knowledge of the violation, then the proxy would be completely void. Then, if a sufficient number of proxies were

58 Subin v. Goldsmith, 224 F.2d 753, 762 (2d Cir.), cert. denied, 350 U.S. 883 (1955). 59 Cf. Central Foundry Co. v. Gondelman, I66 F. Supp. 429 (S.D.N.Y. 1958).

60 One cannot properly speak of the purchasing corporation or the corporation with which the voting corporation is merging as having rights even after the shareholder vote approving the merger or sale. Unless contracts have already been signed subject merely to ratification-and even then by making provision for those rights-the directors can abandon the plan of sale or merger despite the shareholder vote. See, 'e.g., GaL. CoRp. Code $\S 4112$ (1962); ILI. Rev. Stat. ch. 32, § 157.70 (1963); N.Y. Bus. Corp. LAw \& 903 (1963); N.C. GEN. STAT. § 55-108(c) (1960). See generally LATTIN, Corporations 527 (1959). Therefore the corporation which is the subject of the shareholder election with which we are concerned has at best an interest revocable by the other board of directors for a time after the vote. The shareholder vote itself is not conclusive. 
void, the corporate election would be void. This might well result in injury to those who, without knowledge of the violations, had acquired rights from the corporate election. Therefore, in the context of 14(a), section 29(b) should be read as making the proxies void "except insofar as a finding of voidness will affect the rights of those who have no knowledge of the violations." 61 This paraphrased reading will be followed in the subsequent analysis.

Of the three different arguments which can be made for the existence of a private action under section 14(a), only the argument based on section 29(b) supports an action to set aside a consummated corporate act.

\section{STANDING}

Under the implied civil remedy theory a plaintiff who can show injury resulting from a violation of the proxy rules has an action for damages. Under the "private SEC" theory, any stockholder may bring an action for preventive relief for a violation of the proxy rules. Although the applicability of either of these theories to section 14(a) has not been clearly established, the case law of the lower federal courts grants them consistent though somewhat inarticulate recognition. The central issue in Borak is the scope of the remedy available under the provision of section 29(b) voiding contracts in violation of the act.

One way in which the courts could limit the remedy available under section $29(\mathrm{~b})$ is by imposing a strict standing requirement. Under the implied civil remedy theory the plaintiff need only show injury. ${ }^{62}$ And under the "private SEC" theory, an action brought by anyone adversely affected facilitates enforcement of the act. But standing to allege voidness under 29(b) presents more difficult conceptual problems. At common law, the only person who has standing to complain of a contract which has been induced by misrepresentation is the party to the contract who

61 Proxies were declared partially void in Textron $v$. American Woolen Corp., 122 F. Supp. 305 (D. Mass. 1954). The court held that any misleading statement was only with regard to the intention to vote for management in the election of directors, therefore the vice went only to the exercise of the proxies on that particular matter. The violation was held not to invalidate the proxies for all purposes; they could be voted for a quorum and other matters considered at the meeting. This solution is desirable in some respects for it involves the least disruption to the corporation and most of the parties and eliminates the expense of resolicitation of proxies and postponement of the meeting. The shareholders whose proxies were partially voided would be disfranchised so far as the election is concerned, however.

But the declaration of partial invalidity was made for the wrong reasons, resulting from an examination of particular issues. Partial voidness on particular issues is improper under section 29(b). Rather, as this comment suggests, any decree constituting less than a declaration of total voidness should be because of innocent parties' rights which are affected.

62 See 2 HARPER \& JAMEs, TORTS $\$ 17.6$ (1956). 
was misled. If he is not interested in vindicating his rights, the courts should not be willing to do it for him at the behest of another party. In the context of proxy contracts, the shareholder who has given a proxy has the right to have it voted as he directed. If he learns of a misrepresentation and is still happy with his bargain, it may be argued the courts should not set it aside at the behest of another. Such a concept would thus require that the action be brought by a person who has given a proxy in response to a solicitation containing misrepresentations, on behalf of all stockholders similarly situated.

On the other hand, allowing other shareholders to bring an action would facilitate enforcement of the act. But such a plaintiff would merely be acting as a representative of the public interest. Yet the SEC itself does not have standing under $21(\mathrm{e})$ to undo corporate acts. It could be argued that a private plaintiff whose standing arises only from the fact that his action facilitates enforcement of the act should be similarly restricted to preventive relief. Furthermore, a private party who seeks to challenge the corporate act after the election but who had not given a proxy was probably already disenchanted with those he now accuses of a proxy violation. Restricting him to preventive relief would minimize the disruption to the corporation ${ }^{63}$ caused by "strike suits" brought

63 Ironically, availability of relief to set aside corporate acts may lead courts not to grant the temporary injunction necessary to make preventive relief effective on the ground that irreparable injury has not been shown. See Mack v. Mishkin, 172 F. Supp. 885 (S.D.N.Y. 1959).

But preventive relief is obviously more desirable than relief after a meeting is concluded and elections certified or other acts consummated. While preventive relief is disruptive, it is less so than undoing consummated corporate acts. Nevertheless, the practical difficulties in which a court finds itself when preventive relief is sought, particularly in a contested election where the relief itself may become a factor in the contest, is well illustrated in Mack $v$. Mishkin. Suit was brought by a dissident shareholders group to enjoin management from continued use of allegedly false and misleading proxy material and from using any proxies obtained by means of such solicitation. The court reviewed the allegations and concluded there were substantial issues of fact, the resolution of which would require a full scale trial. Conceding there was authority for granting preliminary relief even when such substantial questions remained (citing SEC v. May, 134 F. Supp 247 (S.D.N.Y. 1955), aff'd., 229 F.2d 123 (2d Cir. 1956); SEC v. Torr, 87 F.2d 446 (2d Cir. 1937)), the judge nevertheless held against the plaintiffs. He believed the plaintiffs had not convinced him of the fair probability of ultimate success since the SEC staff had approved the proxy material and the SEC, with full knowledge of the facts presented by the plaintiffs, had not brought an action. He thought it would be "indulgence in mere speculation and conjecture" to hold that a fair probability of ultimate success had been demonstrated.

The judge also concluded the harm to the defendants from granting the petition for injunction would outweigh the harm to the plaintiffs if the election took place. He reasoned that the granting of the injunction would come to the attention of other shareholders, a substantial number of whom would conclude that the granting of preliminary relief was tantamount to a final determination of wrongdoing on the part of management. Therefore, granting the injunction "could well assure the plaintiffs of 
for purposes of harassment or to give the plaintiff a bargaining lever. ${ }^{64}$ Nevertheless, if the objective of the act is the protection of shareholders and the public interest is in a violation-free electoral process, then the fact that the plaintiff's motive may not be the purest is not of importance and he should be allowed to sue, not only for preventive relief as a surrogate SEC but also for retrospective relief, either under section 29(b) or a general theory of undoing a wrong to enforce the act.

Discussing whether a shareholder who has not given a proxy should be allowed to bring an action under section 14(a), Professor Loss comments:

Moreover, in principle it is difficult to see why there should be any limitation of this sort on the private right of action under $\S$ 14(a). The remedy is based not on any concept of the proxy attorney's violation of a fiduciary obligation to his principal, but on the premise that either side in a contested solicitation has a legitimate interest, in view of the statutory purpose, to cry "Foul" against the other.65

Loss appears to speak only of the contested corporate election. In such cases the need for a private remedy after the election may be minimal. The stricter SEC contest rules are in effect and each side is scrutinizing

ultimate success in their eventual aim, i.e., control of the corporation." $I d$. at 889 . The court concluded by citing Professor Loss as authority for the conclusion the SEC could later sue to set aside the corporate election, therefore a private plaintiff could seek the same relief.

One can sympathize with the court's difficulty. Nevertheless, in many cases a stay of the election or corporate action while the facts are resolved is preferable to upsetting the action thereafter. The courts should be ready to grant preventive relief rather than create uncertainty over whether acts already achieved might be upset. Granting also that preliminary relief may itself be a psychological factor in the contest, that should not affect the court's judgment on enforcement of the act. Perhaps it is necessary to assume as a corollary to the concept of shareholder democracy that investors are enlightened enough to understand the subtleties of the judicial process. As to the court's reliance on the lack of action by the SEC, section 26 of the act, 48 Stat. 902 (1934), as amended, 15 U.S.C. $\$ 78 z$ (1958), explicitly states that action by the SEC or failure to act is not to be construed to mean it has approved the transaction or that any statement or report filed with it is not misleading. The Commission's silence, says Professor Loss, should certainly not be fatal to a plaintiff's case. "Otherwise there would be no point in recognizing a private right of action at all." 2 LOSS, SECURITres REGULATION 953 (1961). He points out that budget considerations and other demands on the SEC staff may make involvement by the SEC in private litigation less frequent, as may the Commission's reluctance to inject itself in election campaigns. The courts have at times drawn an inference from the Commission's silence, though Loss feels it may have been when they were not disposed to find a violation anyway. Id. at 953-54 \& n.375.

64 Of course, it is possible that the private civil action could become a form of federal "strike suit." Should such abuses appear in private actions, legislation may be necessary to require the reasonable posting of security for expenses in such federal actions.

652 Loss, op. cit. supra note 63 , at 947. 
the acts of the other. But only a small percentage of proxy solicitations are contested. In uncontested elections enforcement of the act would be materially furthered by allowing shareholders who did not give proxies to cry "foul" after the election has taken place. For it is in the routine and uncontested corporate solicitation that proxy rule violations are most likely to slip by undetected. One of the purposes of the 1934 act is to guarantee to all shareholders a violation-free election. Even those who have not themselves given proxies to the violators have been deprived of this right. Their standing to complain of their deprivation should be recognized. ${ }^{66}$

\section{The State Law Issues}

The theory which may be invoked to upset a consummated corporate act is that the proxies were void under section 29(b). But in applying the provision of section 29 (b) that a proxy contract is void only as to the rights of violators and non-violators with knowledge (in terms of the paraphrase here proposed, that a proxy contract is void only in so far as its voidness does not affect the rights of non-violators without knowledge of the violation) the federal courts must look to state law. For it is only in state law that a corporate election has meaning. The legal significance of a proxy, the conditions under which it may be given or exercised, how many are necessary to achieve corporate acts-all these matters are determined by state law. It was the necessary confrontation of these state issues which led the Dann court to limit remedies under section 14(a). But the Dann court failed to recognize that these state issues are only a step in the process of vindication of the federal right. In order to determine in what respects a proxy is void, a federal court must look to see whose rights would be affected by a declaration of proxy invalidity under state law. To simply declare the proxies void in toto, as the Dann court did, is to evade the crucial issue.

The solution of the state law issues is not an insurmountable problem. Although no state has a statute prohibiting fraudulent, false or misleading statements in proxy solicitation analogous to the federal statute, ${ }^{67}$ it is possible to work out solutions from general principles of state corporation

66 The procedural requirements for shareholders' derivative actions in the federal courts may be deemed applicable to civil actions based on violations of $\S 14(a)$, depending on whether the suit is characterized as derivative or individual. See discussion, supra note 13. If FED. R. Crv. P. 23(b) is held applicable, the plaintiff must have been "a shareholder at the time of the transaction of which he complains or . . . his share [must have] thereafter devolved on him by operation of law ...." Ibid. See generally 3 MOORE, FEDERAI Practice \I 23.18 (2d ed. 1948).

672 Loss, op. cit. supra note 63, at 945. Although a few state cases have involved claims under the state common law of fraud or misleading statements in proxy solicitations, see note 78 infra, there are few holdings on the merits. 
law. Proxies are important under state corporations statutes primarily in constituting a quorum for shareholder meetings, in approving extraordinary corporate acts such as sales of assets, mergers or consolidations and in electing directors. Examination of the corporation law in a few representative states-California, ${ }^{68}$ Delaware, ${ }^{69}$ Illinois, ${ }^{70}$ New York, ${ }^{71}$ North Carolina, ${ }^{72}$ and the Model $\mathrm{Act}^{73}$ - as well as general writings on corporate matters reveals, however, that the effect of void proxies on subsequent corporate acts is unclear.

All the statutes set forth quorum requirements, but of the six statutes examined here, only California and North Carolina have explicit statutory provisions regarding impropriety. Both provide:

Shares shall not be counted to make up a quorum for a meeting if voting for them at the meeting has been enjoined or for any reason cannot be lawfully voted at the meeting. ${ }^{74}$

If the proxies are not counted and a quorum is, therefore, absent, under the above statutes the meeting would be declared not to have been convened. All action taken at the meeting would be of no effect. Resolicitation of proxies for a new meeting would be decreed giving all shareholders an opportunity to vote at a meeting free of unfairness.

But to declare the results of the entire meeting invalid because of lack of a quorum would probably drastically affect innocent parties and subsequently acquired interests. This is especially true in view of the fact that all actions requiring stockholder approval would be frozen until the process could be re-enacted. Adherence to the reading of section 29(b) here proposed would avoid such harsh results. Whenever a declaration of proxy invalidity for purposes of quorum would affect the rights of non-violators without knowledge of the violation, then the proxies should not be declared void for purposes of quorum.

Under state law, completed mergers and sales of assets generally are upset only when there is gross fraud or unfairness in the transaction, or severe conflicts of interest. ${ }^{75}$ This rule reflects in part a feeling on the part of the state courts that the disenchanted shareholders should

68 Cal. Corp. CODE. (1962).

69 DeL. Code ANN. tit. 8 (1953).

70 Ill. REv. STAT. ch. 32 (1963).

71 N.Y. Bus. CoRP. LAw. (1963).

72 N.C. GEN. STAT. $\$ 55(1960)$.

73 ABA-ALI MOdel Bus. CoRp. ACT (1955).

74 CAL. Corp. Cone $\$ 2211$ (1962); N.C. GEN. STAT. \$ 55-65 (1960) (the North Carolina statute omits the final words "at the meeting").

75 Ballantine, Corporations § 285 (1946); Latrin, Corporations ch. 11, 6 (1959). 
be left to their appraisal remedy. The reluctance to grant rescission and other remedies is also due in large part to the many interests affected, such as those of subsequent purchasers of shares of the merged corporation. ${ }^{76}$ The more conditions have changed during delay before litigation, the more ready state courts have been to apply equitable barriers such as laches. 77

It is possible that a court zealously endeavoring to protect the shareholders might be tempted to reject votes procured by fraud or other misrepresentation despite the fact the transaction was consummated. One case dealing with proxy fraud has intimated that such a result would be proper. In Lieferant $v$. Bartell ${ }^{78}$ a derivative action to enjoin a merger had been dismissed and the merger consummated under Delaware law. An action seeking to upset the merger was pursued and came to trial, at which time the case was settled. Other shareholder-plaintiffs sought to intervene. The court allowed the intervention because it agreed with a referee's finding that the plaintiffs had a substantial chance of undoing the merger due to unfairness in the proxy solicitation leading to the merger, and also because an injunction proceeding had been started before the merger. The court relied on an equitable principle that starting such legal action, even if unsuccessful, may be notice to the parties if they go ahead and consummate the merger. This case suggests that, if the proxy votes cast approving a merger or sale of assets were in fact void, dissolution of the merger or rescission of the sale may be an appropriate remedy.

Since a finding of proxy invalidity on a vote approving a merger or sale of assets would affect rights of the corporation with which the merger was consummated, or rights of the person acquiring the assets, such a declaration should be made-under the interpretation of section 29(b) here proposed-only if those parties had knowledge of the proxy violations. By traditional rules of agency, a corporation would have such knowledge when its officers did. Under the facts alleged in Borak, for example, the rights of ATC in the merger might be voided because its officers had knowledge and were violators. The chief problem an order dissolving such a merger would raise would be protection of subsequent purchasers of shares of the merged corporation. But where such purchasers are not substantial in number, it should be possible to work out effective arrangements for the protection of their interests.

State courts have held that an election of directors and officers con-

76 Ballantine, op. cit. supra note 75; Fletcher, Private Corporations §§ 7159-60 (rev. ed. 1961).

7770 A.L.R. 53 (1931).

7836 Misc. 2d 477, 232 N.Y.S.2d 1003 (Sup. Ct. 1962). 
ducted at an illegal meeting must be set aside. ${ }^{79}$ In dealing with claims of voting irregularity, state courts usually require that the plaintiff show that a changed result would follow from a finding for the plaintiff before the court will hear the case. ${ }^{80}$ Once the plaintiff has established that there were voting irregularities, the New York courts have held that they may provide no relief other than ordering a new election ${ }^{81}$ which they have done in a few cases where sufficient misrepresentation was shown to invalidate proxies at common law. ${ }^{82}$ In other states the courts may order new elections, but are often authorized to give other relief as well. ${ }^{83}$ In Delaware, for example, the courts will decree the election of defeated candidates without holding a new election. ${ }^{84}$

If a new election is ordered, those who gave the proxies which were declared void will not be disenfranchised but will have their opportunity to vote. If a changed result is decreed after throwing out void proxies these shareholders lose their franchise. On the other hand the expense and time required for a new election is avoided if the court declares the changed result as the result of the election. In determining which solution is appropriate, state law is, of course, properly considered. But the court may also wish to consider the percentage of proxies wrongly solicited and declared void. Where the percentage of proxies solicited in violation of section 14(a) is low, the easiest solution may be to void the election of violators and declare the election of those who would have won discounting the voided proxies. Where the percentage of void proxies is high, the interest in avoiding disenfranchisement of large numbers of shareholders would suggest that a whole new election is in order.

The requirement of section 29 (b) that proxies should be voided only in so far as their voidness does not affect the rights of non-violators without knowledge raises two separate problems in the context of director elections. The first is the rights of the directors themselves. Although the case of a non-violating and unknowing director who is elected to office as the result of a material proxy violation must indeed be rare, the reading of section $29(\mathrm{~b})$ here proposed would protect such a director.

79 See M \& E Luncheonette v. Freilich, 30 Misc. 2d 637, 218 N.Y.S.2d 125 (Sup. Ct. 1961).

80 Application of Morrison, 7 App. Div. 2d 42, 180 N.Y.S.2d 760 (1958); Matter of R. Hoe \& Co., 137 N.Y.S.2d 142 (Sup. Ct. 1954), aff'd, 285 App. Div. 927, 139 N.Y.S.2d 883, aff'd, 309 N.Y. 719, 128 N.E.2d, 420 (1955).

81 Aranow \& Einhorn, Proxy Contests for Corporate Control 456 (1957).

82 Wyatt v. Armstrong, 186 Misc. 216, 59 N.Y.S.2d 502 (Sup. Ct. 1945); In re Scheuer, 59 N.Y.S.2d 500 (Sup. Ct. 1942). But see Matter of R. Hoe \& Co., 137 N.Y.S.2d 142 (Sup. Ct. 1954), aff'd, 285 App. Div. 927, 139 N.Y.S.2d 883, aff'd, 309 N.Y. 719, 128 N.E.2d 420 (1955).

83 See ArAnow \& EInhorn, op. cit. supra note 81, at ch. 19.

84 Id. at $472-75$ and cases discussed therein. 
But a court might well be willing to void the election of such a director in any case. It is true that a working director may have given up other positions or interests upon his election to the board, but on the whole a director's rights to his office do not involve that element of reliance which makes the position of the subsequent good faith purchaser so deserving of protection. The second problem which section 29(b) raises in the context of director elections is the rights of non-violators without knowledge of the violation who have dealt with the corporation since the directors' election. This problem will require that the federal court examine the de facto doctrine of the state. Generally, this doctrine holds that the acts done by directors or officers who assume they were legally elected-though they were not-and the contracts made by the officers or directors with parties who have no reason to suspect deficiencies in the election have the same validity as if the officers or directors were properly in office..$^{85}$ In New York, however, in a case in which a quorum was lacking at the meeting, the court held "the special election of directors at the meeting ... and all subsequent actions taken by them were a nullity." 88 A de facto doctrine following this last case could create harsh results. If innocent third parties who have entered into contracts with the corporation would lose their rights if the election were set aside, the court must be sensitive to their rights before proceeding to set aside elections. But in a state with the usual de facto doctrine federal courts would be able to upset the director elections without affecting the rights of innocent third parties.

A cumulative voting state may raise special problems. Under a cumulative voting system a minority block may have the power to elect one director. If the qualifications of the candidate so elected were misrepresented in the proxy solicitation material, either a new election or a declaration that the defeated candidate who received the next largest number of votes is elected would defeat the minority block's voting power and its right to concentrate its votes. If state law would allow one of these remedies, it should be decreed. ${ }^{87}$ Otherwise the only solution would seem to be to hold a whole new election.

\section{The Scope of the Federal Remedy}

Many questions of effects in state law thus must be determined by the federal court. They must be determined in order to rule on the

85 Lattin, Corporations 234 (1959).

86 M \& E Luncheonette v. Freilich, 30 Misc. 2d 637, 643, 218 N.Y.S.2d 125, 131 (Sup. Ct. 1961).

87 Compare Janney v. Philadelphia Trans. Co., 387 Pa. 282, 128 A.2d 76 (1956), with Wolfson v. Avery, 6 I11. 2d 78, 126 N.E.2d 701 (1955), involving cumulative voting and the classification of directors. 
primary federal question involved, for the nature of the federal right is such that it is founded on state law concepts. But the suit is still one arising under federal law for that law creates the cause of action. ${ }^{88}$ The right to full and fair disclosure in corporate elections by proxy is a federally created right. State law will be considered in fashioning a remedy, but that fact in no way alters the federal court's responsibility to vindicate the right or its authority to do so. And in so doing, as both the Dann and Borak courts recognized, the federal courts in their equity jurisdiction have complete authority to grant whatever remedies are appropriate and to give a complete remedy for violation of the federal right:

[W] here federally protected rights have been invaded, it has been the rule from the beginning that courts will be alert to adjust their remedies so as to grant the necessary relief. And it is also well settled that where legal rights have been invaded, and a federal statute provides for a general right to sue for such invasion, federal courts may use any available remedy to make good the wrong done.89

In fashioning the remedy, the federal court is not restricted by the designation of specific remedies in the statute but may exercise its discretion. The cases cited in Borak and in the SEC's amicus curiae brief ${ }^{90}$ in the Seventh Circuit support this conclusion. Thus, under the Securities Act of $1933^{91}$ the Supreme Court held that purchasers of securities were not limited to recovery from the persons specified in section $12^{92}$ of the act but could proceed against third parties having assets belonging to the vendor. The jurisdictional section, section 22(a),93 of the 1933 act is virtually identical (except for the word "exclusive") to that of the 1934 act. Of it the Court said:

The power to enforce implies the power to make effective the right of recovery afforded by the Act. And the power to make the right of recovery effective implies the power to utilize any of the procedures and actions normally available to the litigant according to the exigencies of the particular case. ${ }^{94}$

Likewise in other cases the Court has authorized grants of equitable

88 See Smith v. Kansas City Title \& Trust Co., 255 U.S. 180, 214 (1921) (Holmes, J., dissenting).

89 Bell v. Hood, 327 U.S. 678, 684 (1946).

90 Brief for the SEC as Amicus Curiae, pp. 9-11, Borak v. J. I. Case Co., 317 F.2d 838

(7th Cir. 1963).

9148 Stat. 74 (1933), as amended, 15 U.S.C. $\$ 77$ (1958).

9248 Stat. 84 (1933), as amended, 15 U.S.C. $\$ 771$ (1958).

9348 Stat. 86 (1933), as amended, 15 U.S.C. $\$ 77 v(a)$ (1958).

94 Deckert v. Independent Shares Corp., 311 U.S. 282, 288 (1940). 
remedies beyond the explicit provisions of the statute involved. Ordering restitution of rent overcharges under the wartime Emergency Price Control Act was upheld ${ }^{95}$ though the act provided for an injunction or an order enforcing compliance. The Court explicitly reaffirmed the principles enunciated in that decision in allowing reimbursement for loss of wages from a discharge unlawful under the Fair Labor Standards Act of $1938 .{ }^{96}$ The Court has also upheld the ordering of divestiture and dissolution under the general illegality language of the Sherman Act. ${ }^{97}$

The above cases, combined with the implications of the 1934 act itself-particularly sections 28 and 29-and general principles of federal equity jurisdiction affirm the fact that the federal courts have the equity power to fashion appropriate remedies in private actions for proxy violations. The Dann court implicitly recognized this fact in admitting that its holding "would be eating away at the vital principle that for every federal right, there should be a complete federal remedy." 98

\section{Abstention}

Rather than vindicate the federal right, the Dann court abstained. It did so because of considerations of federal-state comity, because of concern for crowded federal court dockets, and, especially, because of the many questions of state law which were involved.99

It may be noted that the concern for crowded dockets is not an important one. It will be a rare case which, like Dann, does not involve diversity. Consequently, the action would likely be on the federal docket anyway. The scope of the federal question right is crucial to parties because of security for costs and other matters. It is of great moment for court dockets only to the extent that the full disposition of the case in federal court helps promote judicial economy by preventing split litigation and the necessity for the plaintiff to bring his action in both federal and state courts in order to provide insurance against being later barred by laches or limitation in a state court. But those considerations point to a result opposite that of the Dann court.

Dann is essentially an abstention case. The court abstained because of the number of issues of state law which had to be determined. Such abstention is improper. The fact that state law is unsettled or case law non-existent-as on some of the questions of effects in state law of void proxies-is not sufficient reason for the federal court to abstain. The

95 Porter v. Warner Holding Co., 328 U.S. 395 (1946).

96 Mitchell v. Robert DeMario Jewelry, Inc., 361 U.S. 288 (1960).

97 Schine Chain Theatres, Inc. v. United States, 334 U.S. 110 (1948).

$98288 \mathrm{~F} .2 \mathrm{~d}$ at 214.

99 Ibid. 
doctrine of abstention is a special one, generally disfavored by the Supreme Court, and only to be invoked in particular cases where there exist certain "narrow and extraordinary" grounds and "exceptional circumstances."100

The first class of cases in which abstention may be required is comprised of actions involving claims for relief based on the federal constitution in which, by abstaining, the court avoids prematurely reaching a constitutional issue. ${ }^{101}$ The second class arises generally in diversity cases which involve certain special issues and in which the law of the state is conflicting or unsettled. In these cases abstention has been allowed to avoid decision where the federal action would interfere with the formation or definition of state public policy, ${ }^{102}$ with administrative processes, ${ }^{103}$ criminal processes, ${ }^{104}$ fiscal and tax policy ${ }^{105}$ or financial institutions. ${ }^{106}$ The Supreme Court has not been tolerant of abstention in diversity cases involving other state matters. ${ }^{107}$

100 The language is Mr. Justice Brennan's, writing for the majority in County of Allegheny v. Frank Mashuda Co., 360 U.S. 185 (1959), and for the dissenters in Louisiana Power \& Light Co. v. City of Thibodaux, 360 U.S. 25, 32 (1959). Justice Frankfurter used similar language for the majority in Thibodaux.

101 Clay v. Sun Ins. Office Ltd., 363 U.S. 207 (1960); Martin v. Creasy, 360 U.S. 219 (1959); Harrison v. NAACP, 360 U.S. 167 (1959); Stainback v. Mo Hock Ke Lok Po, 336 U.S. 368 (1949); Railroad Comm'n of Texas v. Pullman, 312 U.S. 196 (1941). See also cases cited in Kurland, Toward a Cooperative Judicial Federalism, 24 F.R.D. 481, 488 n.39 (1959).

102 Burford v. Sun Oil Co., 319 U.S. 315 (1943); Railroad Comm'n of Texas v. Rowan \& Nichols Oil Co., 311 U.S. 570 (1941).

103 Central Kentucky Nat. Gas Co. v. Railroad Comm'n, 290 U.S. 264 (1933).

104 Douglas v. Jeannette, 319 U.S. 157 (1943); Beal v. Missouri Pac. R.R., 312 U.S. 45 (1941); Spielman Motor Sales Co. v. Dodge, 295 U.S. 89 (1935).

105 Great Lakes Dredge \& Dock Co. v. Huffman, 319 U.S. 293 (1943); Stratton v. St. Louis Southwestern Ry., 284 U.S. 530 (1932); Matthews v. Rodgers, 284 U.S. 521 (1932).

106 Gordon v. Washington, 295 U.S. 30 (1935); Pennsylvania v. Williams, 294 U.S. 176 (1935).

107 See Meredith v. Winter Haven, 320 U.S. 228 (1943), in which the Court emphasized that since Congress created the diversity jurisdiction, the federal courts were not freed by Erie R.R. v. Tompkins, 304 U.S. 64 (1938), from deciding questions of state law and added, "Instead it placed on them a greater responsibility for determining and applying state laws in all cases in their jurisdiction in which federal law does not govern." Id. at 237. The Court has similarly held where the state issue involved the exercise of state eminent domain, County of Allegheny v. Frank Mashuda Co., 360 U.S. 185 (1959), or difficult questions of state law affecting the internal affairs of corporations, Williams v. Green Bay \& W.R.R., 326 U.S. 549 (1946). But cf. Louisiana Power \& Light Co. v. City of Thibodaux, 360 U.S. 25 (1959), a decision which at the time was felt to broaden the abstention doctrine and make more lenient the conditions of its application in diversity cases. Brennan dissenting, id. at 31, 32; Kurland, supra note 101; Note, 13 Vand. L. REv. 801, 814 (1960); Comment, 69 Yale L.J. 643 (1960). Such broadening has not yet occurred and the decision may well have been due to the peculiar nature of the state law conflict in which the district court was caught, see 
The federal question abstention cases involving non-constitutional issues are the most important in consideration of whether a federal court may abstain from deciding doubtful state law in actions under the proxy rules. The cases indicate the federal courts have an obligation to exercise the jurisdiction conferred on them. In Markham $v$. Allen, ${ }^{108}$ a suit by the Alien Property Custodian under the Trading with the Enemy Act, ${ }^{109}$ state law was ambiguous and the matter was already in a state probate court. Reversing a Ninth Circuit holding allowing abstention, the Supreme Court said, "the mere fact that the district court, in the exercise of the jurisdiction which Congress has conferred on it, is required to interpret state law is not in itself a sufficient reason for withholding relief to petitioner." 110 In another case under the same act the Court pointed out that where a non-constitutional federal issue depends for its resolution on underlying state law issues, "the practice ... [is] to decide both issues."111 A similar holding resulted in a federal estate tax controversy in which Illinois law, which was not clear, was crucial to the result.112

Congress made a judgment as to which courts would have jurisdiction to decide questions under the proxy rules when it created exclusive jurisdiction in the federal courts. The courts have jurisdiction to grant complete relief to vindicate the federal right. The language of Markham above is thus apt; the fact that the court is required to interpret state law is not a sufficient reason for withholding relief.

However, since the federal courts have exclusive jurisdiction of proxy rules violations, questions of the effect of void proxies on elections, mergers, sales of assets or other corporate acts under state law may never arise in state courts. Such cases should be rare because of the vigilance of the SEC in prior review of the proxy materials; nevertheless in cases in which the federal courts do entertain suits for equitable relief because of proxy. violations, they might make all the case law on the effect of void proxies under state law. If this proves to be of concern to the states and they wish to avoid it, they may assume the responsibility of clarifying their own law and making their own policy in any of several ways. Statutes similar to section 14 of the Exchange Act could be enacted making misrepresentation in proxy solicitation illegal as a

Kurland, supra, a conflict between the statute and an opinion of the state attorney general.

108326 U.S. 490 (1946).

10940 Stat. 411 (1917), 50 U.S.C.A. App. \& 1 (1951).

110326 U.S. at 495.

111 Propper v. Clark, 337 U.S. 472, 490 (1949).

112 Estate of Spiegel v. Comm'r, 335 U.S. 701 (1949). 
matter of state law, perhaps embodying the standards of the SEC proxy rules. The state courts as a matter of common law might allow proxy actions on the strict standards of the federal proxy rules. State legislatures can clarify the state corporation law provisions to make clear the effect of proxy misrepresentation on mergers and sales of assets. The problem for the federal courts, the states, and the litigants would also be made easier if more states adopted statutory provisions like that of Florida allowing the federal courts to certify particular issues directly to the state supreme court for opinion.113

Absent state action on any of the above methods, the federal court under its exclusive jurisdiction may not abstain from deciding the necessary, though unclear, state law issues. The issues involved do not raise a sufficient state interest of the kind which demands abstention so that the state courts may have the first opportunity to resolve the doubtful issues of state law. For example, they do not nullify state action "close to the political interests of the state."114 In fact, in the context of the proxy rules, they involve issues of corporation law the results of which affect the purposes and prophylactic nature of the Securities Exchange Act. The discretion of a federal chancellor is at least as suitable as that of a state chancellor to decide these questions against the background of the objectives of the 1934 act.

\section{Conclusion}

It should not be forgotten that in federal court consideration of actions to set aside corporate acts under section 14(a) two doctrines will play an important role. The first is the requirement that a "material" violation of the rules be shown. The courts have been ready to impose this requirement where preventive relief was requested ${ }^{115}$ and they should be even more careful to do so where the plaintiff desires to void an election already held. With serious results attendant upon a finding of a violation, "technical" violations such as failure to comply with particular filing requirements should stand on a different footing from non-disclosure of facts which might have altered the shareholder's vote. The second doctrine is laches. Where the plaintiff had reason to know of the proxy violation before the election was held, his claim for relief after the election should not be heard.

113 Fla. Stat. Ann. § 25.031 (1961). See, e.g., Dresner v. City of Tallahassee, 84 Sup. C. 235 (1963); Green v. American Tobacco Co., 304 F.2d 70 (5th Cir. 1962); Green v. American Tobacco Co., 154 So. 2d 169 (Fla. 1963).

114 Comment, Louisiana Power of Light v. Thibodaux: The Abstention Doctrine Expanded, 69 YALE L.J. 643, 660 (1960).

115 See 2 Loss, Securrties Regulation 961-62 (1961); cf. Dunn v. Decca Records, Inc., 120 F. Supp. 1 (S.D.N.Y. 1954). 
The rhetoric of "retrospective" and "prospective," of "individual" and "derivative" is not helpful in the solution of the problems presented by Dann and Borak. Straightforward application of the common-law doctrine that an individual who is injured by a violation of a criminal statute and is a member of the class intended to be protected has a civil remedy results in the recognition of a damage remedy for those injured by a proxy violation. However, such a remedy may often be inadequate, both because of the difficulty of computing damages and because of the inability of violators to pay the damages. When the plaintiff asks further relief, to set aside corporate acts based on an election because invalid proxies were used, such relief may be granted under certain circumstances through the provision of section 29(b) which makes the proxy contracts void if made in violation of the rules. But a reading of the apparent intent of the section results in the principle that proxies should not be voided where doing so will affect the rights of persons who were not violators and had no knowledge of the violation. This principle may in fact restrict the court so that retrospective relief will not be granted in particular cases because of the rights which would be affected. Nevertheless the court still has jurisdiction to grant any appropriate equitable relief to a private party. ${ }^{116}$ The argument of the Dann court-ostensibly one of jurisdiction but in fact one of abstentiononly confuses the issues.

116 Congressional action would, of course, be most desirable in clarifying the application of the statute to a situation with which it does not explicitly deal, but such action is most unlikely. Cf. Blau v. Lehman, 368 U.S. 403 (1962); SEC v. Capital Gains Research Bureau, 306 F.2d 606, 611 (2d Cir. 1962). But cf. SEC v. Capital Gains Research Bureau, 84 Sup. Ct. 275 (1963); Wolf v. Weinstein, 372 U.S. 633 (1963). See generally FRIENDLY, The Gap in Lawmaking-Judges Who Can't and Legislators Who Won't, 63 Colum. L. Rev. 787 (1963); KAPLAN, Wolf $v$. Weinstein: Another Chapter on Insider Trading, 1963 Sup. CT. REv. 273. 